\title{
Fattening performance of crossbred (Polish Holstein-Friesian $\times$ Hereford, Limousin or Charolais) bulls and steers offered high- wilted grass silage-based rations
}

\author{
Cezary Purwin ${ }^{1 *}$, Iwona Wyzlic ${ }^{1}$, Zofia Wielgosz-Groth ${ }^{1}$, Monika Sobczuk-Szul ${ }^{1}$,
}

Jacek P. Michalski ${ }^{2}$, and Zenon Nogalski ${ }^{1}$

\section{ABSTRACT}

In Poland beef cattle are usually fed high-wilted grass silage offered ad libitum and supplemented with concentrate, whereas 'Limousin', 'Charolais' and 'Hereford' bulls are the most frequently crossed with dairy cows to produce beef hybrids. The aim of this study was to determine the fattening performance of hybrids produced by crossing 'Polish Holstein-Friesian' (PHF) cows with 'Hereford' (HH), 'Limousin' (LM) and 'Charolais' (CH) bulls, fed silage made from high-wilted grass and supplemented with a small amount of concentrate, depending on sire breed and category. The experimental materials comprised 24 bulls and 24 steers, including $8 \mathrm{PHF} \times \mathrm{HH}, 8 \mathrm{PHF} \times$ LM and 8 PHF $\times \mathrm{CH}$ crosses with initial body weight of approximately $300 \mathrm{~kg}$ in each group. The animals were fed grass silage with a DM content of $417 \mathrm{~g} \mathrm{~kg}^{-1}$, supplemented with concentrate at $35 \mathrm{~g} \mathrm{DM} \mathrm{kg}^{-1} \mathrm{~W}^{0.75}$, for $250 \mathrm{~d}$. Steers were characterized by higher total DM intake per unit of metabolic body weight $(\mathrm{P}<0.05)$ : 92.8 vs. $87.0 \mathrm{~g}$; 94.1 vs. $84.6 \mathrm{~g} ; 88.6$ vs. $87.0 \mathrm{~g}(\mathrm{PHF} \times \mathrm{HH}$; $\mathrm{PHF} \times \mathrm{LM}$; $\mathrm{PHF} \times \mathrm{CH}$, respectively) and bulls - by higher average carcass weight gains ( $\mathrm{P}<0.01)$ : 700 vs. $631 \mathrm{~g} ; 654$ vs. $579 \mathrm{~g} ; 633$ vs. $574 \mathrm{~g}$ and carcass dressing percentage ( $\mathrm{P}<0.01)$ : 60.0 vs. $56.4 \%$; 60.2 vs. $58.9 \%$; 60.2 vs. $56.6 \%(\mathrm{PHF} \times \mathrm{HH}$; $\mathrm{PHF} \times \mathrm{LM}$; $\mathrm{PHF} \times \mathrm{CH}$, respectively) and better $(\mathrm{P}<0.01)$ silage $\mathrm{DM}$, total DM, crude protein, and net energy utilization. Sire breed had no significant effect on the analyzed parameters of fattening performance but numerically $\mathrm{PHF} \times \mathrm{HH}$ crosses had the highest productivity parameters.

Key words: Breed, bulls, fattening performance, highwilted grass silage, steers.

${ }^{1}$ University of Warmia and Mazury in Olsztyn, Faculty of Animal Bioengineering, Oczapowskiego 5, 10-719 Olsztyn, Poland. "Corresponding author (purwin@uwm.edu.pl).

${ }^{2}$ The Kielanowski Institute of Animal Physiology and Nutrition, Polish Academy of Sciences 05-110 Jabłonna, Poland.

Received: 23 October 2015.

Accepted: 11 April 2016.

doi:10.4067/S0718-58392016000300011

\section{INTRODUCTION}

The lifting of milk quotas in the European Union has increased competition between dairy producers. As a result, many farms have converted from milk production to beef production by crossing dairy cows with beef bulls whose offspring are characterized by higher values of average daily gains, carcass dressing percentage, carcass lean content, feed efficiency and meat quality than dairy cattle (Kamieniecki et al., 2009; Pesonen et al., 2013a). The breed of beef sires used for crossing is the main determinant of performance parameters and carcass quality traits in crossbred calves (Simcic et al., 2009; Huuskonen et al., 2013). In Poland, 'Limousin', 'Charolais', and 'Hereford' bulls are most frequently crossed with dairy cows to produce beef hybrids (Nogalski et al., 2014). The above breeds are characterized by different growth rate and fattening ability. Cattle breeds used in breeding programs should be carefully selected to produce calves well adapted to environmental conditions, and to meet market demand (Albertí et al., 2008).

In Poland, mostly young bulls are fattened due to their higher average daily gains, carcass dressing percentage and feed efficiency, as compared with steers (Nogalski et al., 2013; 2014). However, growing consumer expectations for high-quality beef, even at high prices, have led to the increased popularity of meat from steers. Beef from steers owes its high sensory quality to a higher intramuscular fat content, in comparison with beef from young bulls (Nogalski et al., 2014). Due to their lower blood testosterone levels, steers are mild-tempered and less prone to stress, which is particularly important during the pre-slaughter period as it prevents the depletion of energy reserves required for decreasing muscle $\mathrm{pH}$ (Nogalski et al., 2013).

Due to the low profitability of cattle fattening in Poland, beef cattle are fed roughage exclusively or roughage-based diets supplemented with a small amount of concentrate. Maize silage is too expensive to be fed to cattle due to high costs of maize production, including expenses associated with disease and pest control and the use of specialist harvesting equipment (Purwin et al., 2010). In Poland, where grasslands have a high share of total land area and the growing season is relatively short, beef cattle are usually fed grass silage offered ad libitum and supplemented with concentrate up to $40 \%$ total DM intake (Nogalski et al., 2013). In most cases, silage is made from grass wilted to $40 \% \mathrm{DM}$ and placed in bunker silos, which prevents secondary fermentation without the need to use expensive additives. However, it may also lead to non-uniform packing density and insufficient compaction of the forage in horizontal silos, excessive heating and feedout losses, 
thus decreasing the energy value of silage, protein quality and silage intake (Purwin et al., 2014a). Silage made from high-wilted grass is characterized by a lower rate of organic matter digestibility in comparison with silage made from unwilted grass. In the latter case, more intensive hydrolysis of structural carbohydrates is observed during the ensiling process (Purwin et al., 2009). In most studies investigating the fattening performance of 'Hereford', 'Limousin', and 'Charolais' cattle and their crosses, the animals were fed direct-cut grass silage or silage made from grass wilted to $30 \%$ DM (Huuskonen et al., 2007; Huuskonen, 2008; Pesonen et al., 2013a; 2013b). The existing knowledge could be expanded by analyzing the performance of dairy/ beef crosses fed silage made from high-wilted grass and comparing the fattening ability of young bulls and steers.

The objective of this study was to determine the fattening performance of hybrids produced by crossing Polish 'Holstein-Friesian' cows with 'Hereford', 'Limousin', and 'Charolais' bulls, fed silage made from high-wilted grass and supplemented with a small amount of concentrate, depending on sire breed and category.

\section{MATERIALS AND METHODS}

\section{Animals, feeds, housing and diets}

A fattening trial was conducted at the Agricultural Experiment Station in Bałcyny $\left(53^{\circ} 35^{\prime} \mathrm{N}, 1^{\circ} 51^{\prime} \mathrm{E}\right)$ in northeastern Poland. A $3 \times 2$ factorial design was used to study the effects of sire breed ('Hereford' HH, 'Limousine' LM, and 'Charolais' CH) and category (bulls and steers). The experimental materials comprised 24 bulls and 24 steers, including respectively eight hybrids produced by crossing Polish 'Holstein-Friesian' cows with 'Hereford' bulls (PHF $\times \mathrm{HH})$, eight with 'Limousin' bulls $(\mathrm{PHF} \times \mathrm{LM})$ and eight with 'Charolais' bulls $(\mathrm{PHF} \times \mathrm{CH})$.

Calves of known origin purchased at 2 or 3 wk of age were placed in a rearing facility. One half of the calves were castrated at purchase. Bloodless castration was carried out by looping an industrial rubber elastrator ring, in accordance with the generally accepted standards. The calves were fed milk replacer, hay and concentrate, followed by haylage. From $130 \mathrm{~kg} \mathrm{BW}$ until the transfer to the fattening unit, the animals were fed grass silage ad libitum, which was also offered ad libitum during fattening, and concentrate at $2.5 \mathrm{~kg}$ animal ${ }^{-1} \mathrm{~d}^{-1}$. Control fattening was started at approximately $300 \mathrm{~kg} \mathrm{BW}$, after a 30-d adaptation period in the fattening unit. After $250 \mathrm{~d}$, animals were transported over a distance of $90 \mathrm{~km}$ to the abattoir. After $24 \mathrm{~h}$ fasting and weighing, they were slaughtered in accordance with industrial standards.

Over the entire fattening period, the animals received 35 $\mathrm{g} \mathrm{DM} \mathrm{kg}^{-1} \mathrm{~W}^{0.75}$ concentrate in four portions per day, from a concentrate feeding station (Insentec, Marknesse, The Netherlands), and grass silage ad libitum. Silage intake was monitored individually using the Roughage Intake Control System (Insentec BV, Marknesse, The Netherlands). There were five animals per roughage feeding station on average. Silage was dosed from a self-propelled feed cart (Seko,
Curtarolo, Italy) and delivered to feeding stations twice daily (at 08:00 and 16:00 h). The amount of concentrate offered to animals was adjusted at 14-d intervals, at control weighing before the morning feeding.

Experimental silage was produced in concrete horizontal silos, from first-cut grasses (Lolium perenne L., Phleum pratense L., Festuca rubra L., Poa pratensis L.) Adequate mineral fertilization was applied. Grass was mown at the ear formation stage, with a drum mower. Green forage was tedded once and it was wilted for $24 \mathrm{~h}$ under favorable weather conditions. Wilted green material was harvested using a precision chop forage harvester (7050, John Deere, Moline, Illinois, USA) and it was compacted in horizontal silos with a tractor (laden weight $7770 \mathrm{~kg}$ ) in $0.5 \mathrm{~m}$ layers. Each silo was covered with a polyethylene sheet and weighted down. Silage was produced without additives.

Concentrated feed was composed of $77 \%$ triticale grain, $19 \%$ rapeseed meal, and $4 \%$ mineral-vitamin mix for beef cattle (Cargill, Warsaw, Poland) containing per kg: $235 \mathrm{~g} \mathrm{Ca}$, $79 \mathrm{~g} \mathrm{Na}, 48 \mathrm{~g} \mathrm{P}, 28 \mathrm{~g} \mathrm{Mg}, 500 \mathrm{~g} \mathrm{Fe}, 2000 \mathrm{mg} \mathrm{Mn}, 375 \mathrm{mg} \mathrm{Cu}$, $3750 \mathrm{mg} Z \mathrm{Zn}, 50 \mathrm{mg}$ I, $12.5 \mathrm{mg}$ Co, $12.50 \mathrm{mg} \mathrm{Se}, 250000 \mathrm{IU}$ vitamin A, $50000 \mathrm{IU}$ vitamin $\mathrm{D}_{3}, 1000 \mathrm{mg}$ vitamin E, $909 \mathrm{mg}$ DL-alpha-tocopherol. Salt licks (Lisal M, LNB, Kiszkowo, Poland) were also offered to supplement minerals.

\section{Procedures and chemical analysis}

Silage samples were collected before fattening and once a month during fattening, and were stored at $-25^{\circ} \mathrm{C}$. Thawed samples were dried at $60{ }^{\circ} \mathrm{C}$ in Binder dryers, and were ground in an ultra centrifugal mill (ZM 200, Retsch, Haan, Germany) to a $1 \mathrm{~mm}$ particle size. Concentrate samples were collected together with silage samples.

The proximate chemical composition, D-value and nutritional value of all feeds and concentrations of carboxylic acids, fractions of structural carbohydrates (neutral detergent fiber NDF, acid detergent fiber ADF, and acid detergent lignin ADL), water-soluble carbohydrates (WSC), $\mathrm{pH}$, content of buffer-soluble $\mathrm{N}$ (BSN), protein $\mathrm{N}$, acid detergent-insoluble $\mathrm{N}$ (ADIN), ammonium $\mathrm{N}$ of silages were determined by methods described by Purwin et al. (2010).

Feed conversion was expressed by silage $\left(\mathrm{kg} \mathrm{DM} \mathrm{kg}^{-1}\right)$, concentrate $\left(\mathrm{kg} \mathrm{DM} \mathrm{kg}^{-1}\right)$, total DM $\left(\mathrm{kg} \mathrm{kg}^{-1}\right)$, net energy (UFV from the French "unité fourragère viande" = feed unit for meat, UFV kg-1) and crude protein $\left(\mathrm{g} \mathrm{kg}^{-1}\right)$ utilization per $1 \mathrm{~kg}$ live weight gain and $1 \mathrm{~kg}$ carcass weight gain.

\section{Statistical analysis}

Data were processed statistically using Statistica ver. 10.0 software (StatSoft, Tulsa, Oklahoma, USA). Within each category (bulls, steers), the animals were divided into three groups based on their breed: $\mathrm{PHF} \times \mathrm{LM}, \mathrm{PHF} \times \mathrm{CH}$, and $\mathrm{PHF}$ $\times \mathrm{HH}$. The effects of category and sire breed on fattening traits were determined by the least squares method using the formula:

$$
Y i j k=\mu+A i+B j+(A B) i j+e i j k
$$

where Yijk is the value of the analyzed parameter, $\mu$ is population mean, $A i$ is the effect of category $(1,2), B j$ is 
the effect of breed $(1,2,3),(A B) i j$ is the Category $\times$ Breed interaction, and eijk is random error.

\section{RESULTS AND DISCUSSION}

\section{Feeds}

The chemical composition and calculated net energy content of silage and concentrate, and the fermentation quality of silage are presented in Table 1. The chemical composition of concentrate remained unchanged throughout the experiment because the same batches of triticale and rapeseed meal were used for diet formulation. In comparison with the values reported by Manninen et al. (2011), silage produced in our experiment had a higher NDF content (by 100 to $150 \mathrm{~g} \mathrm{~kg}^{-1}$ DM) and a lower crude protein content (by 10 to $15 \mathrm{~g}$ ), but the noted values were typical of grass silages in Poland (Purwin et al., 2009). A high degree of grass wilting prior to ensiling eliminated secondary fermentation and had a restrictive effect on the fermentation process, as manifested by low concentrations of lactic acid, a high $\mathrm{pH}$ and a high proportion of WSC in silage (Purwin et al., 2010). The low D-value of silage resulted from high concentrations of NDF and ADIN, and limited fermentation. The energy value of experimental silage was below the INRA reference values (IB-INRA, 2009) for silages made from direct-cut and wilted grasses harvested at comparable growth stages. Experimental silage had a high protein nitrogen content, which is typical of wilted grass silages and points to rapid inhibition of protease activity during wilting (Purwin et al., 2014b). However, the content of ADIN, which is indigestible in the small intestine of ruminants was twofold higher in experimental silage than in wilted grass silages described in the literature, which is indicative of high temperatures during ensiling (Purwin et al., 2014b).

\section{Performance}

$\mathrm{PHF} \times \mathrm{HH}$ bulls and steers were characterized by the numerically highest final body weight and the highest total and daily live weight gains (Table 2). Sire breed had nonsignificant effect on the final body weight, feed intake, body weight gain or carcass dressing percentage of bulls and steers. Category significantly influenced silage intake and total feed intake per unit of metabolic body weight $(\mathrm{P}<0.05)$, carcass dressing percentage and carcass weight gains $(\mathrm{P}<$ $0.01)$. Nonsignificant interactions were observed between sire breed and the category of animals. Bulls of all breed groups had numerically higher carcass dressing percentage than steers. In the group of steers PHF $\times$ LM crosses had numerically the highest carcass dressing percentage.

Feed conversion was not affected by sire breed, whereas category had a significant $(\mathrm{P}<0.01)$ effect on silage intake, total feed intake, net energy intake and crude protein intake per kg live weight gain, and all parameters of feed efficiency per kg carcass weight gain (Table 3 ). Regardless of sire breed, silage intake and total feed intake per $\mathrm{kg}$ live weight gain and carcass weight gain were numerically higher in steers than in bulls. PHF $\times \mathrm{HH}$ crossbreeds were characterized by numerically the lowest feed conversion. Dry matter intake per kilogram live weight gain was numerically lower in $\mathrm{PHF} \times \mathrm{HH}$ bulls than in $\mathrm{PHF} \times \mathrm{LM}$ and $\mathrm{PHF} \times \mathrm{CH}$ bulls (by 0.1 and $0.4 \mathrm{~kg}$, respectively), and in $\mathrm{PHF} \times \mathrm{HH}$ steers than in $\mathrm{PHF} \times \mathrm{CH}$ and $\mathrm{PHF} \times \mathrm{LM}$ steers (by 0.2 and $1.0 \mathrm{~kg}$, respectively).

Numerous studies investigating the growth potential of the three analyzed breeds have revealed that 'Charolais' and 'Hereford' cattle are characterized by the highest and lowest average daily gains, respectively (Albertí et al., 2008; Pesonen et al., 2013a). However, in our study sire breed had

Table 1. Chemical composition and nutritional value of feeds.

\begin{tabular}{|c|c|c|c|c|c|c|}
\hline Signification & Silage & SEM & Triticale & Rapeseed meal & Concentrate & SEM \\
\hline $\mathrm{n}$ & 9 & & 1 & 1 & 9 & \\
\hline Dry matter, $\mathrm{g} \mathrm{kg}^{-1}$ & 417 & 10.2 & 881 & 887 & 883 & 8.2 \\
\hline \multicolumn{7}{|l|}{ On DM basis, $\mathrm{g} \mathrm{kg}^{-1}$} \\
\hline Organic matter & 922 & 1.9 & 981 & 927 & 926 & 18.3 \\
\hline Crude protein & 148 & 2.6 & 133 & 388 & 166 & 7.1 \\
\hline Neutral detergent fiber & 571 & 7.9 & 193 & 310 & 198 & 7.9 \\
\hline Acid detergent fiber & 356 & 6.8 & 44 & 228 & 72 & 5.8 \\
\hline Acid detergent lignin & 49 & 2.2 & 13 & 108 & - & - \\
\hline D-value ${ }^{1}$ & 606 & 5.8 & 914 & 785 & - & - \\
\hline Water-soluble carbohydrates & 62 & 7.0 & - & - & - & - \\
\hline Lactic acid & 44 & 2.8 & - & - & - & - \\
\hline Acetic acid & 10 & 1.4 & - & - & - & - \\
\hline Butyric acid & 2 & 0.5 & - & - & - & - \\
\hline Total VFA ${ }^{2}$ & 12 & 1.2 & - & - & - & - \\
\hline $\mathrm{pH}$ & 4.70 & 0.05 & - & - & - & - \\
\hline \multicolumn{7}{|c|}{ Nitrogen fractions, $\mathrm{g} \mathrm{kg}^{-1} \mathrm{~N}$-total } \\
\hline Ammonia-N & 60 & 5.5 & - & - & - & - \\
\hline Protein-N & 557 & 13.4 & - & - & - & - \\
\hline Buffer-soluble-N & 268 & 11.5 & - & - & - & - \\
\hline Acid detergent-insoluble-N & 100 & 5.3 & - & - & - & - \\
\hline Net energy, UFV kg-1 DM & 0.71 & 0.006 & 1.21 & 1.01 & 1.17 & 0.02 \\
\hline
\end{tabular}

${ }^{1}$ Digestible organic matter in DM.

2Sum of formic acid, acetic acid, propionic "acid", butyric acid, isobutyric acid, and valeric acid.

SEM: Standard error of the mean, VFA: volatile fatty acids, UFV: from the French "unité fourragère viande" = feed unit for meat. 
Table 2. Effect of sire breed and category on the fattening performance of crossbred bulls and steers.

\begin{tabular}{|c|c|c|c|c|c|c|c|c|c|c|}
\hline \multirow[b]{2}{*}{ Specification } & \multicolumn{2}{|c|}{$\mathrm{PHF} \times \mathrm{HH}$} & \multicolumn{2}{|c|}{$\mathrm{PHF} \times \mathrm{LM}$} & \multicolumn{2}{|c|}{$\mathrm{PHF} \times \mathrm{CH}$} & \multirow[b]{2}{*}{ SEM } & \multirow[b]{2}{*}{$\mathrm{B}$} & \multirow[b]{2}{*}{$\mathrm{C}$} & \multirow[b]{2}{*}{ I } \\
\hline & Bulls & Steers & Bulls & Steers & Bulls & Steers & & & & \\
\hline Initial live weight, $\mathrm{kg}$ & 305 & 300 & 297 & 297 & 291 & 300 & 2.1 & & & \\
\hline Final live weight, $\mathrm{kg}$ & 597 & 580 & 569 & 543 & 554 & 554 & 6.5 & & & \\
\hline \multicolumn{11}{|l|}{ Daily intake } \\
\hline Grass silage, $\mathrm{kg}$ DM & 5.1 & 5.6 & 4.8 & 5.4 & 4.9 & 5.1 & 0.13 & & & \\
\hline Total, kg DM & 8.5 & 8.9 & 8.0 & 8.7 & 8.1 & 8.3 & 0.14 & & & \\
\hline Net energy, UFV & 8.0 & 8.3 & 7.5 & 8.1 & 7.6 & 7.8 & 0.12 & & & \\
\hline Crude protein, $g$ & 1324 & 1381 & 1248 & 1351 & 1261 & 1295 & 21.8 & & & \\
\hline Grass silage intake, $\mathrm{g} \mathrm{DM} \mathrm{kg}^{-1} \mathrm{~W}^{0.75}$ & 51.7 & 58.1 & 50.5 & 58.2 & 52.2 & 53.9 & 1.32 & & * & \\
\hline Total intake, g DM kg-1 $\mathrm{W}^{0.75}$ & 87.0 & 92.8 & 84.6 & 94.1 & 87.0 & 88.6 & 1.30 & & * & \\
\hline Live weight gain, $\mathrm{kg}$ & 293 & 280 & 272 & 245 & 263 & 254 & 5.4 & & & \\
\hline Daily live weight gain, $g$ & 1170 & 1121 & 1087 & 982 & 1052 & 1015 & 21.7 & & & \\
\hline Carcass dressing percentage, $\%$ & 60.0 & 56.4 & 60.2 & 58.9 & 60.2 & 56.6 & 0.41 & & ** & \\
\hline Carcass weight gain, $\mathrm{g}$ & 700 & 631 & 654 & 579 & 633 & 574 & 12.8 & & ** & \\
\hline
\end{tabular}

PHF $\times$ HH: Crossbred calves sired by Hereford bulls, PHF $\times$ LM: crossbred calves sired by Limousin bulls, PHF $\times$ CH: crossbred calves sired by Charolais bulls, SEM: standard error of the mean, B: sire breed, C: category, I: interaction, UFV: From the French "unité fourragère viande" = feed unit for meat.

${ }^{*},{ }^{* *}$ Significant at the 0.05 and 0.01 probability levels, respectively.

Table 3. Effect of sire breed and category on feed conversion in crossbred bulls and steers.

\begin{tabular}{|c|c|c|c|c|c|c|c|c|c|c|}
\hline \multirow[b]{2}{*}{ Specification } & \multicolumn{2}{|c|}{$\mathrm{PHF} \times \mathrm{HH}$} & \multicolumn{2}{|c|}{$\mathrm{PHF} \times \mathrm{LM}$} & \multicolumn{2}{|c|}{$\mathrm{PHF} \times \mathrm{CH}$} & \multirow[b]{2}{*}{ SEM } & \multirow[b]{2}{*}{$\mathrm{B}$} & \multirow[b]{2}{*}{$\mathrm{C}$} & \multirow[b]{2}{*}{ I } \\
\hline & Bulls & Steers & Bulls & Steers & Bulls & Steers & & & & \\
\hline \multicolumn{11}{|c|}{ Feed conversion/kg live weight gain } \\
\hline Silage, $\mathrm{kg}$ DM & 4.3 & 5.0 & 4.4 & 5.6 & 4.6 & 5.0 & 0.12 & & ** & \\
\hline Concentrate, $\mathrm{kg}$ DM & 3.0 & 3.0 & 3.0 & 3.4 & 3.1 & 3.3 & 0.06 & & & \\
\hline Total, kg DM & 7.3 & 8.0 & 7.4 & 9.0 & 7.7 & 8.2 & 0.16 & & ** & \\
\hline Net energy, UFV & 6.9 & 7.4 & 7.0 & 8.4 & 7.2 & 7.7 & 0.14 & & ** & \\
\hline Crude protein, $\mathrm{g}$ & 1136 & 1244 & 1154 & 1397 & 1198 & 1278 & 24.6 & & $* *$ & \\
\hline \multicolumn{11}{|c|}{ Feed conversion $/ \mathrm{kg}$ carcass weight gain } \\
\hline Silage, kg DM & 7.3 & 8.9 & 7.4 & 9.5 & 7.7 & 8.8 & 0.23 & & ** & \\
\hline Concentrate, $\mathrm{kg}$ DM & 5.0 & 5.3 & 5.0 & 5.8 & 5.1 & 5.7 & 0.10 & & ** & \\
\hline Total, kg DM & 12.2 & 14.2 & 12.3 & 15.3 & 12.8 & 14.6 & 0.30 & & ** & \\
\hline Net energy, UFV & 11.4 & 13.2 & 12.6 & 13.0 & 12.0 & 13.6 & 0.22 & & ** & \\
\hline Crude protein, $g$ & 1898 & 2204 & 1915 & 2374 & 1993 & 2260 & 45.5 & & $* *$ & \\
\hline
\end{tabular}

PHF $\times$ HH: Crossbred calves sired by Hereford bulls, PHF $\times$ LM: crossbred calves sired by Limousin bulls, PHF $\times$ CH: crossbred calves sired by Charolais bulls, SEM: standard error of the mean, B: sire breed, C: category, I: interaction, UFV: From the French "unité fourragère viande" = feed unit for meat.

${ }^{*},{ }^{* *}$ Significant at the 0.05 and 0.01 probability levels, respectively.

no impact on the growth rate of $\mathrm{PHF} \times \mathrm{CH}$ or $\mathrm{PHF} \times \mathrm{HH}$ crosses, and PHF $\times$ HH bulls and steers had numerically higher daily live weight and carcass weight gains than their continental counterparts.

Average daily gains recorded in PHF $\times$ LM bulls and steers in our study were lower than those reported by other Polish authors for cattle fed maize silage (Bilik et al., 2009). Average daily gains noted in PHF $\times \mathrm{CH}$ bulls and steers in our experiment were comparable with that reported by Simcic et al. (2009) for Charolais crosses (1032 $\left.\mathrm{g} \mathrm{d}^{-1}\right)$. Purebred 'Charolais' bulls and steers were characterized by higher average daily gains of 1321 to $1557 \mathrm{~g}$ (Pesonen et al., 2013a). In presented study PHF $\times$ HH bulls and steers had the numerically highest average daily gains in all analyzed categories, which could suggest that 'Hereford' cattle are well adapted to fattening system based on grass silage and that under extensive feeding systems beef cattle can achieve high weight gains also when fed diets with a higher proportion of concentrates. High growth potential of 'Hereford' cattle was also demonstrated by Manninen et al. (2011) in whose study finishing 'Hereford' bulls fed grass silage with a high moisture content and D-value of $750 \mathrm{~g} \mathrm{~kg}^{-1}$, supplemented with concentrate at $3.2 \mathrm{~kg} \mathrm{DM} \mathrm{d}^{-1}$, were characterized by average daily gain of 1588 to $1808 \mathrm{~g}$. However, carcass dressing percentage reported in the above study was 4 percentage points lower than in our experiment. In a study by Pesonen et al. (2013a), higher average daily gain was noted in purebred 'Charolais' bulls than in purebred 'Hereford' bulls (1476 g vs. $1300 \mathrm{~g}$ ), but the D-value of the analyzed silage was $667 \mathrm{~g} \mathrm{~kg}^{-1} \mathrm{DM}$.

Nutrient intake per unit of metabolic body weight was lower in our study than in experiments performed by other authors (Keady et al., 2008; Manninen et al., 2011). Silage intake was limited by decreased digestibility and because excessive heating in the silo reduced the palatability and nutrient availability of silage (Krizsan and Randby, 2007).

The average daily live weight gains achieved by PHF $\times$ $\mathrm{LM}$ and PHF $\times \mathrm{CH}$ crosses in our study were unsatisfactory, which suggests that the genetic potential of animals could not be fully realized in the applied dietary treatments. There is evidence that cattle of late maturing breeds are more responsive to protein level in the diet than early maturing breeds (Huuskonen, 2008). Pesonen et al. (2013b) reported crude protein intake of 1282 to $1491 \mathrm{~g}$ in young 'Charolais' bulls. In our experiment, crude protein intake by PHF $\times$ $\mathrm{CH}$ bulls and steers was 21 to $230 \mathrm{~g}$ lower, which resulted 
from relatively low silage intake and its low protein content. Additionally in our study, the BSN content of silage was nearly twofold lower than that noted in typical silages with a DM content lower than $300 \mathrm{~g} \mathrm{~kg}^{-1}$ (Huuskonen et al., 2007; Pesonen et al., 2013a; 2013b). Such proportions of $\mathrm{N}$ fractions in experimental grass silage point to lower availability of $\mathrm{N}$ compounds for the synthesis of bacterial proteins, and to lower digestibility of protein flowing into the intestine (Purwin et al., 2014b).

Crossbred bulls and steers were characterized by similar feed efficiency, which could result from similar DM intake and average daily gains. Nutrient intake per kilogram live weight gain was lower in $\mathrm{PHF} \times \mathrm{HH}$ crosses than in latematuring breeds, which was probably affected by the low D-value of silage (Keady et al., 2008). Feed conversion per kilogram carcass weight noted in $\mathrm{PHF} \times \mathrm{HH}$ bulls was comparable with that reported for purebred $\mathrm{HH}$ bulls by Pesonen et al. (2013b), whereas feed conversion for 'Charolais' crosses was $20 \%$ higher. Protein intake from silage accounted for $56 \%$ to $60 \%$ of total protein intake. It appears that high protein conversion was due to the low quality of protein from high-wilted grass silage.

In comparison with steers, bulls were characterized by significantly higher final body weights, daily carcass weight gains and carcass dressing percentage, and significantly lower feed intake, which resulted from significantly higher feed efficiency. Bulls produce more muscle and deposit less fat than steers (Nogalski et al., 2014). The above differences were observed despite the fact that all animals were housed together in free-stalls, which probably led to greater energy losses in bulls due to mounting each other. The average daily live gains of bulls were lower than expected and lower than those reported by other researchers (Pesonen et al., 2013a), who analyzed feed rations with nutrient concentrations higher than in our study. Higher silage intake on a DM basis was observed in steers, particularly in PHF $\times \mathrm{LM}$ and PHF $\times \mathrm{HH}$ crosses, leading to higher energy and protein intake. In steers, higher energy and protein intake accompanied by a lower ability to synthesize protein contributed to a higher feed conversion ratio (FCR), and due a lower carcass dressing percentage, the differences per kilogram carcass weight gain increased to $16 \%, 24 \%$, and $14 \%$ in $\mathrm{PHF} \times \mathrm{HH}, \mathrm{PHF} \times \mathrm{LM}$ and $\mathrm{PHF} \times \mathrm{CH}$ crosses, respectively.

\section{CONCLUSIONS}

The results of this study indicate that sire breed had nonsignificant effect on the fattening performance of crossbred bulls and steers fed high-wilted grass silage produced in bunker silos. $\mathrm{PHF} \times \mathrm{HH}$ crosses had the highest productivity parameters. Bulls were characterized by better fattening performance than steers, and the greatest differences were found between PHF $\times$ LM crosses. Fattening based on high-wilted grass silage limited the growth potential of $\mathrm{PHF} \times \mathrm{LM}$ and $\mathrm{PHF} \times \mathrm{CH}$ crosses, which have high nutrient requirements.

\section{ACKNOWLEDGEMENTS}

The present research was implemented within the Project nr WND-POIG.01.03.01-00-204/09 Optimizing Beef Production in Poland According to "Fork to Farm" Strategy co-financed by the European Regional Development Fund under the Innovative Economy Operational Programme 2007-2013.

\section{REFERENCES}

Albertí, P., B. Panea, C. Saudo, J.L. Olleta, G. Ripoll, P. Ertbjerg, et al. 2008. Live weight, body size and carcass characteristics of young bulls of fifteen European breeds. Livestock Science 114(1):19-30.

Bilik, K., K. Weglarzy, and Z. Choroszy. 2009. Effect of feeding intensity of Limousin bulls on production parameters and dietetic properties of meat (in Polish). Roczniki Naukowe Zootechniki 36(1):63-73

Huuskonen, A. 2008. Need for protein supplementation in the diet of growing dairy bulls fed total mixed ration based on moderate digestible grass silage and barley. Agricultural and Food Science 17:109-120.

Huuskonen, A., H. Khalili, and E. Joki-Tokola. 2007. Effects of three different concentrate proportions and rapeseed meal supplement to grass silage on animal performance of dairy-breed bulls with TMR feeding. Livestock Science 110:154-165.

Huuskonen, A., M. Pesonen, H. Kamarainen, and R. Kauppinen. 2013. A comparison of purebred Holstein-Friesian and HolsteinFriesian $\times$ beef breed bulls for beef production and carcass traits. Agricultural and Food Science 22:262-271.

IB-INRA. 2009. National Research Institute of Animal Production in Krakow. Revised edition based on "Nutrition standards for cattle, sheep and goats - the nutritional value of feed for ruminants" 2001. Skrzetelski, J. (ed.) (in Polish). Krakow, Poland.

Kamieniecki, H., J. Wójcik, R. Pilarczyk, K. Lachowicz, M. Sobczak, W. Grzesiak, et al. 2009. Growth and carcass performance of bull calves born from Hereford, Simmental and Charolais cows sired by Charolais bulls. Czech Journal of Animal Science 54(2):47-54.

Keady, T.W.J., F.O. Lively, D.J. Kilpatrick, and B.W. Moss. 2008. The effects of grain treatment, grain feed level and grass silage feed value on the performance of and meat quality from, finishing beef cattle. Animal 2:149-159.

Krizsan S.J., and A.T. Randby. 2007. The effect of fermentation quality on the voluntary intake of grass silage by growing cattle fed silage as the sole feed. Journal of Animal Science 85:984-996.

Manninen, M., M.Honkavaara,L. Jauhiainen,A.Nykanen, and A.M. Heikilla. 2011. Effects of grass-red clover silage digestibility and concentrate protein concentration on performance, carcass value, eating quality and economy of finishing Hereford bulls reared in cold conditions. Agricultural and Food Science 20:151-168.

Nogalski, Z., P. Pogorzelska-Przybylek, Z. Wielgosz-Groth, M. Sobczuk-Szul, C. Purwin, R. Winarski, et al. 2013. Effect of fattening intensity and age at slaughter on the carcass value of crossbred beef steers (in Polish). Żywność. Nauka. Technologia. Jakość 3(88):51-60. 
Nogalski, Z., Z. Wielgosz-Groth, C. Purwin, M. Sobczuk-Szul, M. Mochol, P. Pogorzelska-Przybylek, et al. 2014. Effect of slaughter weight on the carcass value of young crossbred ('Polish Holstein Friesian' $x$ 'Limousin') steers and bulls. Chilean Journal of Agricultural Research 74:59-66.

Pesonen, M., M. Honkavaara, and A. Huuskonen. 2013a. Production, carcass and meat quality traits of Hereford, Charolais and Hereford $\times$ Charolais bulls offered grass silage-grain-based rations and slaughtered at high carcass weights. Acta Agriculturae Scandinavica, Section A - Animal Science 63(1):28-38.

Pesonen, M., M. Honkavaara, H. Kamarainen, T. Tolonen, M. Jaakkola, V. Virtanen, et al. 2013b. Effects of concentrate level and rapeseed meal supplementation on performance, carcass characteristics, meat quality and valuable cuts of Hereford and Charolais bulls offered grass silage-barley-based rations. Agricultural and Food Science 22:151-167.

Purwin C., M. Fijalkowska, B. Kowalik, H. Skorko-Sajko, Z. Nogalski, and B. Pysera. 2014a. The effect of bale density and addition of formic acid on the in situ dry matter and crude protein degradation of lucerne, red clover and red fescue silages. Journal of Animal and Feed Science 23:177-184.
Purwin, C., M. Fijalkowska, B. Pysera, K. Lipinski, S. Sienkiewicz, D. Piwczynski, et al. 2014b. Nitrogen fractions and amino acids content in alfalfa and red clover immediately after cutting and after wilting in the field. Journal of Elementology 19(3):723-734.

Purwin, C., B. Pysera, A. Sederevicius, S. Makauskas, A. Traidaraite, and K. Lipinski. 2010. Effect of silage made from different plant raw materials with the addition of a fermentation inhibitor on the production results of dairy cows. Veterinarija Ir Zootechnika 51(73):44-54.

Purwin, C., B. Pysera, M. Tokarczyk, A. Sederevicius, S. Savickis, and A. Traidaraite. 2009. Production results of dairy cows fed grass and alfalfa silage with a different degree of wilting. Veterinarija Ir Zootechnika 46(68):60-66.

Simcic, M., M. Cepon, and S.Zgur. 2009. Growth and carcass traits of young bulls sired by Charolais and Limousin. Italian Journal of Animal Science 8(Supplement 3):267-269. 